\title{
Anker Brink Lund, Lars Nord \& Johann Roppen: Nye udfordringer for gamle medier. Skandinavisk public service i det 21. århundrede. Göteborg: NORDICOM. 2009.
}

\author{
Roel Puijk
}

MedieKultur 2010, 49, 175-178

Published by SMID | Society of Media researchers In Denmark | www.smid.dk The online version of this text can be found open access at www.mediekultur.dk

Da jeg fikk boka Nye udfordringer for gamle medier i hendene, leste jeg på baksiden bl.a. at: "Metodisk er det afgørende nye, at der anlægges et medieøkologisk niche-perspektiv. Derved forsøger forskerne at undgå en normativ for eller imod diskussion. I stedet settes fokus på den innovative og markedskorrigerende betydning af public service på relativt små mediemarkeder som det danske, norsk og svenske." Denne uttalelsen vekket min interesse - hva er det nye ved det medieøkologiske nisjeperspektivet, og hvordan vil forfatterne klare å styre unna normative utsagn? Jeg fikk en del svar - særlig når det gjelder det første spørsmålet.

I første kapittel gjøres det rede for det medieøkologiske perspektivet. Hovedtesen er at mediesystemer som de skandinaviske best kan beskrives som helheter av nasjonale nisjer. Mediemarkedene betraktes som nisjer i økologisk forstand: innenfor nisjene er det et begrenset antall dominerende og avhengige aktører som samarbeider og konkurrerer om knappe ressurser - særlig i form av tid og penger. Koordineringen skjer gjennom markedskonkurranse og mediepolitiske forhandlinger. Dermed blir perspektivet på mange måter politisk økonomi, men med referanser til økologiske og økonomiske begreper som nisjer, overcrowding, og merits. I tillegg anlegges det et innovasjonsperspektiv med referanse til Rogers innovasjonsteorier.

Den teoretiske innfallsvinkelen illustreres ved en gjennomgang av den historiske medieutviklingen mot stadig større konvergens - utviklingen fra presse til radio og fjernsyn viser en oppløsning av grensene mellom nisjene hvor (om jeg kan bruke en biologi-inspirert 
metafor) internett sprer seg som et virus og perforerer veggene. Denne historiske beskrivelsen slutter rundt 1996, som er et tidspunkt hvor public service-kanalene starter sin onlineaktivitet. Utviklingen etter denne datoen er utgangspunktet for de følgende tre kapitler, som tar for seg perioden 1996-2007 i hhv. Danmark, Norge og Sverige.

Kapitlene presenterer parallelle beskrivelser av mediepolitiske diskusjoner og medieutvikling i de tre landene etter 1996, med særlig fokus på innføring av nettet, DAB-radio og digitalt fjernsyn. Beskrivelsene tar for seg massemedienes hovedaktører - aviser, radio og fjernsyn, med spesiell vekt på public service-aktørene. Også de mediepolitiske diskusjonene og reguleringene er viet bra med plass, slik at kapitlene gir en god innsikt i utviklingene i de tre land.

Konvergensprosessene fører til at grensene mellom ulike medier, organisasjoner, innhold, og distribusjonssystemer er blitt mer uklare og at de ulike medieforetakene konkurrerer med hverandre på flere fronter. Kan hende er nåtidens forhold med på å sette tidligere ofte underkommuniserte relasjoner mellom de forskjellige medieaktørene i et nytt lys - i alle fall er det en fortjeneste med boka at også tidligere former for flermedial publisering og kryssende bånd mellom mediene blir satt fokus på.

Det sentrale i bokas siste kapittel er public service-institusjonenes rolle som innovatører, markedsledere og markedskorrektiver, og de markedsmessige, distribusjonsmessige og produksjonsmessige utfordringene og dilemmaene public service-aktørene står overfor i dagens situasjon. Som sentral konklusjon vises det til at hovedutfordringen blir å distribuere allsidig og høy kvalitet på alle relevante plattformer - med andre ord å tilby merit-goder. Begrepet dekker de samfunnsmessige ettertraktede goder (programmer og tjenester) som det private marked ikke greier å levere.

Anker Brink Lund har vært prosjektleder og har hatt hovedansvaret for boka. Dette kommer til uttrykk i introduksjonskapitlet hvor beskrivelsen av den historiske utviklingen har et visst dansk fokus. Riktignok blir forholdene i Norge og Sverige nevnt, men de har noe vedheng-aktig over seg, noe som framstår som en slagside ved det første kapittel. Kapitlet klarer ellers å tydeliggjøre det teoretiske perspektivet med henvisning til historiske illustrasjoner. I kapitlene om utviklingen i de tre landene er framstillingen bedre parallellført, selv om innledningene presenterer delvis forskjellige opplysninger for hvert land.

Når det gjelder beskrivelsene av de tre landene er det en fryd å få en sammenhengende beskrivelse av de nokså turbulente årene vi har bak oss. Jeg kjenner nok best til situasjonen i Norge, og det er fint å få satt utviklingen også i de andre skandinaviske landene i system. Av og til er det litt vanskelig å vite hvor nær i tid beskrivelsen slutter, men det er forståelig i en dynamisk sektor som mediesektoren. Heldigvis er kapitlene delt opp i klare avsnitt, slik at det går an å bruke beskrivelsen som et oppslagsverk. Ideelt sett synes jeg nok boka kunne ha fortjent en stikkordliste.

Det nisjeøkologiske perspektivet utvider analyseobjektet til flere medier (plattformer) og får dermed fram at utviklingen innen ett medium ikke kan sees isolert fra de andre. Grunnanalysen baserer seg på atskilte nasjonale markeder. Samtidig som boka gir grundig 
innsikt i utviklingen i hvert av landene, viser den også indirekte at en nasjonal tilnærming kommer stadig mer under press: for det første fordi mange av de politiske diskusjonene blir ført i Brussel og resulterer i stadig nye EU-regulativer, og for det andre fordi de kommersielle spillerne er virksomme i en rekke land.

I boka henvises det regelmessig til EU-regulativer og konsekvensene blir, særlig i siste kapittel, tatt opp i drøftingene. Men EUs avgjørelser som sådanne blir ikke analysert, og de behandles som eksterne faktorer som man må forholde seg til. De landsoverskridende strategiene til de kommersielle aktørene er heller ikke gjenstand for analyse. Men det framgår at landegrensene er av mindre betydning for disse - store kommersielle aktører som Schibsted, Egmond, og MTG dukker opp både i Danmark, Norge og Sverige. Nå er verken EU-politikken eller disse kommersielle aktørene fokus for analysen, så det er ingen innvending mot boka, men det er tydelig at det finnes dynamikker som går utover enkelte land. Eller, for å holde meg til bokas terminologi, så endrer nisjene seg ikke bare i form av stadig nye deltakere; også deres utstrekning blir større.

Mer sentralt i bokas resonnementet er argumentet om at public service-kringkastere spiller en viktig rolle som innovatører slik at de små nordiske markedene ikke blir hengende etter teknologisk. Dette er selvsagt noe som er vanskelig å bevise. Den kontrafaktiske utviklingen, hva ville ha skjedd om en ikke hadde public service-aktører - er jo ikke kjent. Analysene tilsier at public service-kringkasterne er framdrivere i utviklingen av digital radio (DAB) og digital bakkebasert distribusjon av fjernsyn (DTT). På nett-området viser beskrivelsen at det var først og fremst i Danmark at public service-selskapene var en primær drivkraft i å lage ettertraktet innhold på nasjonalspåket. I Norge lå en kommersiell medievirksomhet (VG) i teten, mens det i Sverige var vanskelig å få til synergieffekter pga. oppsplittingen av public service-virksomheten i tre selvstendige enheter (SR, SVT og UR).

Jeg er imidlertid forholdsvis skeptisk til argumentasjonen, og spør meg om forfatterne kanskje har valgt å konsentrere seg om de områdene hvor public service-aktørene er mest aktive? Hvis man ser på andre distribusjonsteknologier, som satellitt, kabelfjernsyn eller IP-TV, så er public service-kringkastere ikke særlig på banen. Dette er områder hvor andre aktører er virksomme - private, kommersielle, delvis globale selskap. Disse aktørene er i langt mindre grad behandlet i analysene. I første kapittel illustreres utviklingen med en figur hvor fire sirkler representerer de ulike plattformnisjene (aviser, radio, fjernsyn og P\&T). Mens historien til aviser, radio og fjernsyn blir gjennomgått, er historien til distributørene (P\&T-nisjen) ikke nevnt med et ord. Dette henger også sammen med at plattformbegrepet er nokså uklart - så vidt jeg kan se blir begrepet rett og slett ikke definert.

Dette bringer meg til argumentet at public service-mediene har større mulighet til innovative prosjekter fordi de kan kryssubsidiere - i praksis ved å bruker lisenspengene til noe annet enn det de opprinnelig var tenkt til. På denne måten ble f.eks. fjernsynet i Norge igangsatt med radiolisenspenger, mens nett-tilbudet ble utviklet med lisenspenger som kreves av folk som har fjernsyn. Jeg er klar over at dette skjedde, men hver gang det skjer blir det kritisert. Dessuten er jeg ikke så sikker på at kommersielle aktører ikke er flinke til å 
utvikle innovasjoner i små markeder - i private bedrifter er det mye lettere å overføre ressurser fra en del av virksomheten til en annen, og multinasjonale selskap har jo mulighet til å overføre innovative konsepter, teknologi og kompetanse fra et land til et annet. Men det er klart at de neppe investerer store beløp uten å ha forventninger om å tjene penger på investeringene.

Jeg avslutter med å komme tilbake til det siste spørsmålet jeg stilte i starten. Unngår boka de normative spørsmålene om for eller imot public service? I den økonomiske terminologien er det ytre sett ikke rom for normative betraktninger om kvalitet. Eller er det slik? Et sentralt begrep i hele analysen av public service-kringkastere er merits. Men hva er merit-produksjon mer konkret? På den ene side er det snakk om programmer på nasjonalt språk, som er like dyre å produsere enten det dreier seg om land med et lite eller stort språkfellesskap. Kommersielle kringkastere har derfor tendens til å importere utenlandske programmer heller enn å produsere egne. Et godt eksempel er TV 3, som baserer seg først og fremst på amerikanske serier. Men merits er noe mer; det dekker også andre programmer som de kommersielle aktørene ikke dekker. Hva de består av er imidlertid ikke godt å se i denne boka, ettersom det ikke gjøres noen analyse av tilbudene.

Å hevde at public service-kanalene tilbyr merit-goder gir ikke presise svar på hvilke deler av tilbudet som bidrar til å gi samfunnsnyttige tilskudd til de kommersielle kanalene. En kan vel ikke påstå at all virksomhet til public service-kringkastere har merit-karakter. Som boka riktig nok påpeker, må public service-kanalene balansere mellom popularitet (high reach), allsidighet og pluralisme (broad scope) for å overleve. Forutsetningen som ligger til grunn for i det hele tatt å kunne snakke om meritgoder, er for det første at det er bra å opprettholde små (nasjonale) språkfellesskap, og for det andre at samfunnet har behov for en offentlig mediesfære hvor samfunnsspørsmål diskuteres - altså er det en nasjonal og en demokratisk korporativ ideologi som ligger til grunnen. At det finnes stor støtte for disse ideologiene i de nordiske landene gjør dem selvsagt ikke mindre normative.

På tross av disse innvendingene - boka kan anbefales for enhver som er interessert i medieutviklingen i de skandinaviske markedene med hovedvekt på public service-kringkasting. De tre undersøkte landene er på mange måter nokså like, og man sammenligner seg ofte med hverandre. Da er det samtidig viktig å vite også hvor utviklingen og diskursene $\mathrm{i}$ de tre landene er forskjellige. Denne typen mer inngående beskrivelser av utviklingstrekk, politiske diskusjoner og sammenhenger mellom de ulike mediene i de tre landene er etter min mening bokas hovedfortjeneste.

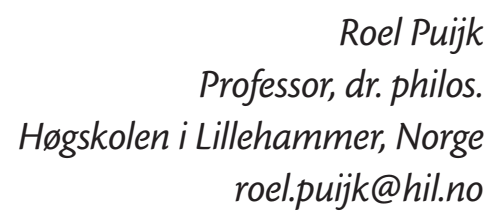

